\title{
SOURCES AND USE OF EXTENSION INFORMATION AMONG MAIZE FARMERS IN RURAL NORTHERN NIGERIA
}

\author{
T. O. Fadiji, T. K. Atala and Jacob P. Voh,
}

\begin{abstract}
This study focused on identification of the main sources of extension information used by farmers who grew improved maize in two villages of Kaduna State, Nigeria. A total of 125 farmers were sampled and based on their responses, data analysis was carried out using descriptive statistics. The findings showed that the relevant sources of extension information available to the respondent farmers were in this order of importance; radio, extension agent, fellow farmers, agricultural shows, village head, slides/film shows, traders, written material and television. Furthermore, findings revealed that the respondents utilized extension information, to a great extent on the following technologies/recommendations; improved maize, seed rate, seed dressing, plant spacing, fertilizer application, post-harvest processing, and storage. Recommendations on herbicides and pesticides were however, not utilized to a great extent by the respondents.
\end{abstract}

Keywords: Extension information, improved maize, utilization, sources of information

\section{INTRODUCTION}

Information is vital to human and societal development. Specifically, extension information is relevant to agricultural practices and development. Consequently, rural farmers play prominent role in dissemination and utilization of extension information.

Sources of extension information available to farmers are diverse and numerous. Generally, extension information is sourced through extension worker, the mass media (i.e. radio and television in particular), printed publications (e.g. newspapers, magazines, bulletins, newsletters, fliers, journals, handbills) and other human groups (i.e. village heads, fellow farmers and traders).

Governments in Nigeria at Federal, State and Local levels have had to intervene or play one role or the other toward ensuring that research-based technologies and recommendations reach the end-users (farmers). However, the farmers in general, indeed the rural farmers in particular, are usually confronted with the problem of identifying the relevant and appropriate sources of extension information on the one hand, and the extent of utilizing the information received from such sources can be optimally used in achieving the so much desired productivity (McAnany, 1980).

Maize (Zea May L.) is a crop popularly grown in many parts of the world. It is a staple food crop found in the diets of many families in Nigeria in general and in the Guinea savannah ecological zone in particular. Its vegetative part is used in making silage for ruminants and the maize crop residue is also a useful source of feed for cattle during the dry season. Maize is cultivated largely in Nigeria by farmers on subsistence and commercial levels taking about 1.8 million hectares of land, which yields an estimate of 1.5 metric tones (representing about $15 \%$ of Nigeria's total grain production). It takes the third position in terms of cultivation and consumption of cereal crops i.e. after sorghum and millet (FAO, 1978). The annual growth rate in area of cultivation to maize was $3.5 \%$ and the annual grain production was 5.3\% (IITA, 1995). According to Walter and Minguel (1994), maize yield in U. S. A. is close to 6 tonnes per hectare per year.

Maize is produced in various colours and sizes; some are classified as open-pollinated varieties (OPVs) while others are hybrids. A distinguishing characteristic of a hybrid is that it must have 15-20\% higher yield than OPVs (Wijk,1994). Data from research has proven that 
hybrid maize impressively performs better in terms of yield than the best of OPVs by as much as $30 \%$ (Kim, 1997). Given adequate agronomic attention, research has shown remarkably that hybrid maize is manageable by an average farmer (Iwuafor, 1997).

This study specifically focused on improved maize growers in two villages namely Kaya and Dan-Ayamaka (in Giwa and Kudan Local Government Areas of Kaduna State, Nigeria). The two objectives of this study are as follows, to; identify the relevant sources of extension information used by improved maize growing farmers, and determine the extent to which they utilize such information.

\section{METHODOLOGY}

This study specifically focused on improved maize growers (farmers) in two villages i.e. Kaya and Dan-Ayamaka in Kaduna State, Nigeria. Both villages have been exposed to extension activities through Government and private intervention/programmes, thus making this study very relevant. With the Nigerian 1991 population figures, Kaya and Dan- Ayamaka were put at 5,530 and 680 persons, respectively.

Through a combined instrumentality of purposive and random sampling techniques, 75 and 50 improved maize growing farmers in Kaya and Dan-Ayamaka respectively were sampled, in the year 2000. They were administered with structured questionnaire and followed up with interview. The data obtained from the administration of questionnaire and interviews were decoded, analyzed and interpreted accordingly.

\section{RESULTS AND DISCUSSION}

The background problem in this study was how to isolate the sources of relevant extension information among farmers who grow improved maize. Hence, the first objective of the study was to identify the sources of relevant extension information available to them. The results indicate that the following sources of extension information were identified by farmers, namely; radio, television, printed material, village head, agricultural shows, extension agents, fellow farmers, slides/film shows, and traders.

Results further show the distribution of respondents according to sources of deriving extension information (Table 1) based on nine selected technologies/recommendations, namely; improved maize, seed rate, seed dressing, plant spacing, fertilizer application, herbicides treatments, pesticides application, post-harvest processing and storage.

Based on the findings the following relevant sources extension information were identified by the respondents: Data in Table 1 shows that a total of 825 scores was allocated to radio as a relevant source of extension information on all the nine technologies/recommendations selected. This put radio on the highest score and taking the first position. Thus, it can safely be concluded that radio was a widely used medium of getting extension information among improved maize growers. Hence, this result is in agreement with earlier reports by Yazidu (1973), Voh (1981), McAnany (1980) and Chikwendu et al (1996) - all of which stressed the values and importance of radio as a source of information. 
Table 1: Distribution of respondents by sources of deriving extension information on selected technologies/recommendations $(n=125)$

\begin{tabular}{|c|c|c|c|c|c|c|c|c|c|}
\hline \multirow{2}{*}{$\begin{array}{l}\text { Technology } \\
\text { / } \\
\text { Recommen } \\
\text { dation }\end{array}$} & Radio & $\begin{array}{l}\text { Ext. } \\
\text { Agent }\end{array}$ & $\begin{array}{l}\text { Fellow } \\
\text { farmer } \\
\text { s }\end{array}$ & $\begin{array}{l}\text { Agric } \\
\text { Show } \\
\text { s }\end{array}$ & $\begin{array}{l}\text { Village } \\
\text { Head }\end{array}$ & $\begin{array}{l}\text { Slides } \\
\text { /film } \\
\text { shows }\end{array}$ & Traders & $\begin{array}{l}\text { Written } \\
\text { material } \\
\text { s }\end{array}$ & $\begin{array}{l}\text { T.V } \\
\text {. }\end{array}$ \\
\hline & \multicolumn{9}{|c|}{ Scores by respondents } \\
\hline $\begin{array}{l}\text { Improved } \\
\text { maize } \\
\text { Seed rate } \\
\text { Seed } \\
\text { dressing } \\
\text { Plant } \\
\text { spacing } \\
\text { Fertilizer } \\
\text { application } \\
\text { Herbicides } \\
\text { Pesticides } \\
\text { Post-harvest } \\
\text { proc. } \\
\text { Storage }\end{array}$ & $\begin{array}{l}116 \\
98 \\
94 \\
91 \\
111 \\
73 \\
73 \\
92 \\
77\end{array}$ & $\begin{array}{l}97 \\
88 \\
81 \\
93 \\
94 \\
54 \\
56 \\
78 \\
80\end{array}$ & $\begin{array}{l}86 \\
58 \\
76 \\
54 \\
81 \\
31 \\
32 \\
62 \\
77\end{array}$ & $\begin{array}{l}78 \\
54 \\
63 \\
51 \\
74 \\
45 \\
45 \\
54 \\
63\end{array}$ & $\begin{array}{l}103 \\
46 \\
70 \\
38 \\
90 \\
29 \\
25 \\
30 \\
44\end{array}$ & $\begin{array}{l}57 \\
33 \\
47 \\
31 \\
63 \\
26 \\
22 \\
36 \\
51\end{array}$ & $\begin{array}{l}74 \\
11 \\
37 \\
6 \\
61 \\
18 \\
24 \\
6 \\
74\end{array}$ & $\begin{array}{l}84 \\
23 \\
51 \\
15 \\
61 \\
14 \\
10 \\
17 \\
31\end{array}$ & $\begin{array}{l}1 \\
1 \\
2 \\
1 \\
2 \\
1 \\
1 \\
0 \\
1\end{array}$ \\
\hline Total & 825 & 721 & 557 & 527 & 475 & 366 & 311 & 306 & 10 \\
\hline Rank & $1^{\text {st }}$ & 2nd & 3rd & $4^{\text {th }}$ & $5^{\text {th }}$ & 6th & 7th & 8th & 9th \\
\hline
\end{tabular}

\section{N.B: Multiple responses were recorded}

Extension agent was identified by the respondents as another main source of extension information. Table 1 further indicates that a total of 721 scores was apportioned extension agent by the respondents thus taking the second position after radio. Consequently, this result tallies with earlier reports by Williams (1969), Yazidu(1973), Voh (1981) and Chikwendu et al(1996).

Farmers also serve as facilitators of information and its dissemination on extension cum farm practices. Table 1 further confirms this i. e. a total of 568 scores was apportioned to Fellow farmers, giving it the third position. The reason for this impressive development is not far fetched - as most of the farmers relate with one another on virtually daily basis - so, there is a tendency to pass information on recommended technologies to one another frequently and easily.

Agricultural shows were identified, in this study, as a veritable source of extension information to the respondents. They gave it a total of 527 scores, taking the fourth position. It is noted generally that agricultural shows is customary in villages from season to season during which farmers exchange ideas and pass extension information and other related ideas to one another. It is understandable that village heads exert influence so much on the people they lead and are quite useful in passing information in general, and extension information in particular, from one to another. According to the data received and indicated in Table 1, the respondents gave Village heads as a source of extension information, a total score of 475 thereby taking the fifth position. Thus, Village heads are reckoned with in dissemination of extension information by the use of their vantage positions, to the farmers and indeed, to the improved maize growers.

The use of Slides and film shows in disseminating extension messages in the rural areas has been established through this study. Results show that a total of 759 scores, representing the sixth in position, was accorded Slides and film shows (Table 1) - as another 
means of obtaining extension information by the improved maize growers.

In this study, the sampled farmers identified traders as a source of getting extension information. The result in Table 1 indicated that the respondents allocated a total of 311 scores to it - thus taking the seventh position. Traders, through this result, show that they are rarely used for extension information sourcing by the respondents, and in general, the improved maize growers. This may be due to the fact that traders are generally illiterates and only have contacts with farmers occasionally - during the market days or during the process of selling their proceeds from farms.

Written materials were found, in this study, to be another source of extension information among the respondents. According to the result, a total of 306 scores was allocated to written materials - thus placing it on the eight position. This apparent low score, compared to others, could be traced to high illiteracy rate associated with rural dwellers and village populations who are hardly given formal education. Consequently, it is inconceivable for a substantial number of them to source extension information from written materials. Besides, such written materials are usually printed matters produced in English and rarely in their vernacular.

Television was identified as a source of extension information among the respondents. Results indicated in Table 1 indicates however that television had the lowest score of mere 10 - thus putting it in ninth position. It can thus safely be concluded that farmers hardly patronized television in getting extension information. Some of the reasons for this low performance on television might be due to high cost a television set; lack of electricity to villages to be used to power it; few programmes been broadcast on television and the language used for the broadcast are usually not in the respondents' native language.

\section{Objective 2:}

The second objective of this study specifically focused on determining the extent to which the improved maize growers utilized extension information. In this connection, the scores allotted to the respondents were classified into the following rates, namely; Frequently (3), Occasionally (2), Rarely (1) and Never (0) - in relation to each of the selected technologies/recommendations on improved maize (Table 2).

Table 2: Distribution of respondents according their extent of adoption of selected technologies/recommendations $(n=125)$

\section{Extent of adoption by the respondents}

\begin{tabular}{|l|l|l|l|l|l|l|l|l|}
\hline $\begin{array}{l}\text { Technologies/ } \\
\text { Recommendations }\end{array}$ & \multicolumn{3}{|l|}{ Frequently } & \multicolumn{2}{l|}{ Occasionally } & \multicolumn{2}{l|}{ Rarely } & \multicolumn{2}{l|}{ Never } \\
\hline & No. & $\%$ & No. & $\%$ & No. & $\%$ & No. & $\%$ \\
\hline Improved maize & 77 & 61.6 & 48 & 38.4 & 0 & 0 & 0 & 0 \\
\hline Seed rate & 37 & 70.4 & 87 & 29.6 & 0 & 0 & 0 & 0 \\
\hline Seed dressing & 25 & 20 & 81 & 65.8 & 15 & 12 & 4 & 3.2 \\
\hline Plant spacing & 18 & 14.4 & 105 & 84 & 1 & 0.8 & 1 & 0.8 \\
\hline $\begin{array}{l}\text { Fertilizer } \\
\text { application }\end{array}$ & 116 & 92.8 & 4 & 3.2 & 0 & 0 & 5 & 4 \\
\hline Herbicides & 1 & 0.8 & 1 & 0.8 & 2 & 1.6 & 121 & 96.8 \\
\hline Pesticides & 32 & 24.8 & 58 & 52 & 2.3 & 13 & 12 & 9.6 \\
\hline $\begin{array}{l}\text { Post-harvest } \\
\text { processing }\end{array}$ & 57 & 45.6 & 48 & 38.4 & 9 & 7.2 & 11 & 8.8 \\
\hline
\end{tabular}

Results show that $61.6 \%$ of sampled farmers frequently used improved maize technology while $38.4 \%$ of them occasionally used it. This situation could be described as impressive 
because the highest percentage of the respondents grew improved maize frequently. Hence, they could be considered as strong adopters of improved maize. Therefore, improved maize could be regarded as an important technology useful for farmers in the rural areas in terms of extension information sourcing and utilization. According to the results, none of the respondents used improved maize rarely and never. This shows that most of them were high adopters of the technology.

It was found that $70.4 \%$ of the respondents used recommended seed rate occasionally while $29.6 \%$ of them used it frequently. This situation could be attributed to the tendency for farmers to ignore the recommendation on seed rate, their preference for local seeds, lack of education or enlightenment on the seed rate, and their planting more seeds per hole in anticipation of getting high yield. It is interesting to note also that none of the respondents used seed rate recommendation rarely and never.

Results indicated that respondents engaged in seed dressing mainly occasionally $(65.8 \%)$. However, $20 \%$ of them used it frequently while $12 \%$ did so rarely and $3.2 \%$ not at all. It could be noted that with those who adopted seed dressing occasionally, the high percentage could be due to the perceived assumption by farmers that seed dressing might not be necessary . Even though $20 \%$ of the respondents applied seed dressing frequently, this could not be assumed to be encouraging enough. The proportion of respondents in the category of Never $(3.2 \%)$ could give one a false impression that those who adopted seed dressing were many.

Findings on adoption of recommended practices on plant spacing by the respondents show that $14.4 \%$ of them did so frequently, $84 \%$ occasionally, $0.8 \%$ rarely and $0.8 \%$ not at all. Specific to the highest percentage of occasional adoption of recommendations plant spacing, it is safe to conclude that farmer used their discretion a lot on plant spacing. Thus, to a great extent, the farmers could be assumed to utilized recommendations on plant spacing.

Results on the adoption of application of fertilizer recommendation show that $92.8 \%$ of farmers adopted it frequently, 3.2\% occasionally, $4 \%$ not at all and none rarely. The high percentage of high adopters in the result is understandable from the point of view that appropriate and adequate application and use of required dosages of fertilizer determines the yield to be obtained on cultivation of improved maize. Thus, most farmers were prone to comply religiously with the recommendations on fertilizer application in anticipation of high yield.

Results on the adoption by farmers sampled on the extent of their adoption of recommendations on herbicides show that the majority of the respondents $(96.8 \%)$ did not use it at all, only $1.6 \%$ rarely, $0.8 \%$ occasionally and $0.8 \%$ frequently. Generally, it can safely be concluded therefore that herbicides was poorly adopted by the respondents. Basically, the reasons attributable to this development could be due to the following factors; availability of alternative means of controlling weeds (e.g. hoeing), high cost of herbicides and the risk associated with its usage. Consequently, most rural farmers would rather control weeds in their farms through manual and cheaper method.

Results of the distribution of respondents on the extent of their adoption of pesticides recommendations indicate that $77.6 \%$ of them did not use it at all, $0.8 \%$ did so frequently, $20.8 \%$ occasionally and $0.8 \%$ frequently. This shows that information on pesticides and its adoption by the respondents were hardly given due attention. Like herbicides, pesticides could be costly for farmers to procure, difficult to use and rarely available - which could make its adoption hard.

Results obtained on the extent of adoption of post-harvest processing technologies by the respondents show that $24.8 \%$ did so frequently, $52 \%$ occasionally, $13.6 \%$ rarely and $9.6 \%$ not at all. The apparent impressive performance on the results concerning both occasional and frequent adopters of this technology could be due to the farmers desire to preserve their farm 
produce in order to avoid or reduce losses. Hence, they naturally seek to get and use information on post-harvest processing technologies more.

Findings on the extent of adoption of recommendations on storage techniques by the respondents show that they did so in the following degrees; $45.6 \%$ frequently, $38.4 \%$ occasionally, $7.2 \%$ rarely, and $8.8 \%$ not at all. With this situation, the respondents adopted a great deal technologies on storage techniques. The reason for this might be unconnected with their desire to preserve their farm produce and avoid losses, which normally arise from lack of proper storage.

\section{CONCLUSION}

From this study, the following conclusions have been reached;

(1). Nine (9) sources of extension information were identified by the respondents. The three mostly used were radio, extension agents and fellow narmers.

(2). Dissemination of extension information should be intensified in the rural areas and due attention be paid to the following sources, namely; extension agents, radio, television and written materials. These have been noted to be veritable media that can reach wide and large audience.

(3). Most of the respondents adopted to a great extent the following recommendations and technologies; improved maize, seed rate, seed dressing, plant spacing, fertilizer application, post-harvest processing and storage techniques. Efforts should therefore be geared more by all tiers of Governments towards encouraging farmers to improve their adoption on herbicides and pesticides, which received low adoption in the studied areas.

(4). Specifically, more extension information on herbicides and pesticides should be given to rural farmers in terms of public enlightenment campaigns, and mass information mobilization.

(5). Finally, farmers in general, and rural farmers in particular, should be encouraged to seek for extension information on recommendations and technologies through various sources of extension information available at their disposal.

\section{REFERENCES}

32: $94-106$

Food and Agriculture Organization (FAO) (1978) Production Year Book, 1977, No.

International Institute of Tropical Agriculture (IITA), 1994-95. (1995) Annual Report. P.55.

Iwuafor, E. N. O. (1997) Improved agronomic practices for production. In: J. A. Valencia, A. M. Falaki, S. Miko, I. U. Abubakar, J. Jaryum and S. G. Ado (eds.). Maize Production and Utilization in Nigeria: Prospects and Constraints. Proceedings of the National Maize Workshop, held July 22, 1996 and August 1997, Kawo - Kaduna, Kaduna State, Nigeria. Pp 63-68.

Kim, S. K. (1997) Increased maize production with hybrid maize seed technology in Nigeria. In: J. A. Valencia, A. M. Falaki, S. Miko, I. U. Abubakar, J. Jaryum and S. G. Ado (eds.) Maize Production and Utilization in Nigeria: Prospects and Constraints. Proceedings of the National Maize Workshop, held July 22, 1996 and August, Kawo - Kaduna, Kaduna State, Nigeria. Pp 69-74.

McAnany, E. G. (1980) The role of information in communication with the rural poor: Some reflections. In: Communications in the Rural Third World (Ed. By Emile G. 
McAnany). Praeger Publisher, U.S. A. Pp3-16.

Walter, J. and Minguel, J. (1994) Maize hybrids in Latin America: Issues and Adoptions. In: Biotechnology and Development Monitor, No. 19: 6-8.

Wijk, J. van (1994) Hybrids, bred for superior yields, or for control? In: Biotechnology and Development Monitor, No.19: 3-5.

Voh, J. P. (1981) Information sources and awareness of selected recommended farm practices: A study in a village in Kaduna State of Nigeria. In: African Journal of Agricultural Sciences, Vol. 8, Nos. 1 \& 2: 77-87. 